\title{
Obituaries
}

\section{David Tyrrell}

Virologist who unlocked many of the secrets of the common cold

David Tyrrell ran the Medical Research Council common cold unit for most of its existence. Though he never found a cure, he discovered almost everything we know about cold viruses and was made a fellow of the Royal Society. At the start of his research it was assumed that there was a single cold virus, which could, perhaps, be prevented or cured. By the end, it was known that there were around 200 , which was why it is so difficult. $\mathrm{He}$ was the first to identify most of them. He discovered most of the secrets of the common cold and showed that none of the popular myths about prevention or cure were of any use.

The unit was located at Harvard Hospital, near Salisbury. The prefabricated wooden buildings, made in the United States, were a wartime gift from Harvard University and the American Red Cross in 1940. The unit was intended as a 125 bed infectious diseases hospital to control the epidemics that were expected to result from the second world war, and the United States provided and paid for the doctors and nurses.

In August 1945 the buildings and contents were transferred as a gift from America to the Ministry of Health for research into communicable diseases. The Medical Research Council took over the buildings for research into the common cold.

The unit was originally under the direction of two virologists, Sir Christopher Andrewes and Dr Alick Isaacs, who had both tried to grow cold viruses in the laboratory, with little success. They realised that the premises would make a good place to bring volunteers for research purposes, and oversaw the appointment of David Tyrrell.

He had recently spent three years at the Rockefeller Institute in New York, a centre of excellence for virology. He had an MD with distinction and had already, aged 32, published around 25 papers on clinical, laboratory, and epidemiological aspects of flu and polio viruses. He had discovered a new virus, the enterovirus, and was studying influenza viruses at the Virus Research Institute in Sheffield.

David Tyrrell arrived at Harvard Hospital on 1 April 1957, and in the ensuing years

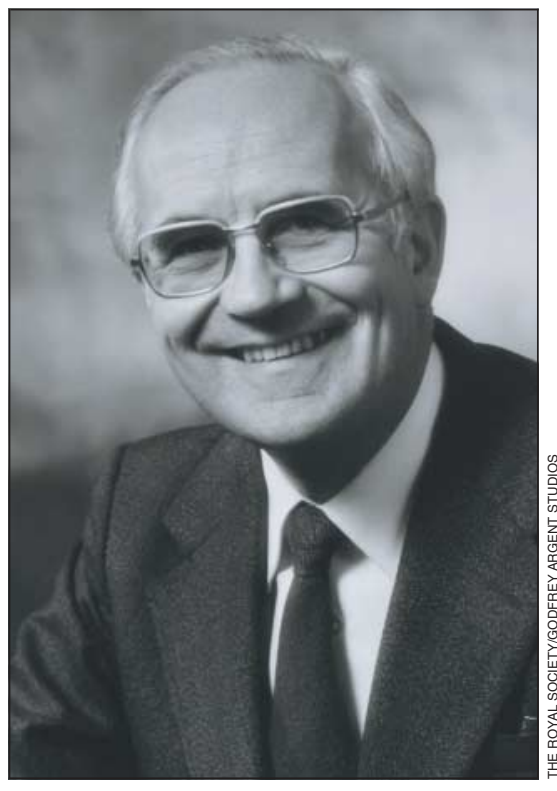

unlocked many of the secrets of the common cold-what it is that makes us catch it, how colds are transmitted, and how they affect our bodies. He identified the causes, and analysed the distribution of the common cold and its international significance. He investigated its psychological implications and put folklore remedies to the test.

Around 20000 volunteers came to Harvard Hospital for 10 days' stay, and many returned year after year. It was a favourite place for students to revise for examinations. They were housed in groups of two or three, as it was thought that isolation would be uncomfortable for them, and they were allowed to walk in the surrounding countryside. Few of the volunteers caught colds, and those that did blew their noses into paper handkerchiefs, which were then weighed and counted.

David Tyrrell worked closely with the World Health Organization, and was director, at the common cold unit, of the WHO Reference Centre for Respiratory Virus Infections.

In 1967 he went to the Medical Research Council's new clinical research centre at
Northwick Park as director of its communicable diseases research unit, combining this work with continuing to oversee research at the unit in Salisbury. Three years later he also became deputy director to Sir Christopher Booth, director of the research centre, who found him helpful and supportive. The MRC closed the clinical research centre in 1984, and Dr Tyrrell returned to the common cold unit until the MRC closed that in 1990.

David Tyrrell published a book, The Common Cold (cowritten with Michael Fielder), in 1991; the BMJ described it as illustrating "beautifully the vagaries, difficulties, false pathways, raised hopes, crashing disappointments, tedium and all too rare but wonderful moments of medical research."

He was also interested in the contribution of viral infections to chronic fatigue syndrome. Until shortly before his death he was chairman of the CFS Research Foundation, and published papers on viruses and fatigue.

He was a committed Christian, and the organist and choirmaster of his local church, and he wore a discreet crucifix in his lapel, but he never proselytised.

David Arthur John Tyrrell was born in Ashford, Middlesex, in 1925, the son of an accountant. The family moved to Sheffield, where he went to King Edward VII School and Sheffield University. He qualified in medicine in 1948 and gained his MRCP a year later, during the three years in which he did various house jobs in Sheffield hospitals. He then went to the Rockefeller Institute.

He was exempted from military service because of a detached retina, and later in his career, when binocular microscopes became the norm, people puzzled why he was happy to still use a monocular one.

Predeceased by his son, he leaves a wife, Moyra, and two daughters. [CARoline RicHMOND]

David Arthur John Tyrrell, director Medical Research Council common cold unit 1957-90, director MRC communicable disease unit 1967-84, and deputy director MRC clinical research centre, Northwick Park, 1970-84 (b 1925; q Sheffield 1948; CBE, FRCP, FRCPath), died from prostate cancer on 2 May 2005. 


\section{Jack Stanley Gibson}

Surgeon who advocated the use of hypnosis as an alternative to anaesthetics

The Irish surgeon Jack Gibson believed in the power of the mind above all else and pioneered the use of hypnosis in surgery for over 40 years. He claimed to have performed more than 4000 procedures without anaesthesia (www.drjackgibson.com/ biography.html) and he inspired several generations of doctors to take up the practice of hypnosis, both in surgery and in treating psychosomatic disorders or disease. $\mathrm{He}$ also claimed to have cured himself of basal cell cancer and chronic varicose veins through self hypnosis.

Jack produced a series of gramophone records, cassette tapes, and CDs from 1965 onwards, dealing with psychosomatic disorders and based on self hypnosis. One of these, How to Stop Smoking, became the best selling LP in Ireland in 1971. He also produced a video entitled The Power of the Subconscious, showing himself performing eye surgery under hypnosis in the 1960s, and he published three books: The Life and Times of an Irish Hypnotherapist (1989), Relax and Live (1992), and Memoirs of an Irish Surgeon-An Enchanted Life (1999).

Jack Gibson was a short, balding dynamo of a man, once a James Mason lookalike, but latterly closer to Nelson Mandela with Ghandi's beautiful smile. $\mathrm{He}$ was a walking contradiction who was the bane of many a hospital hierarchy or high court judge: he was alternative yet conventional, a rebellious yet establishment figure, informal yet intense, self mocking yet proud.

After qualifying in 1933 and becoming a fellow of the Royal College of Surgeons of Ireland in 1934, he did locums in Aden, Malawi, and South Africa. In 1939 he became dean of the Medical Aids School (later known as the Durban Medical School). During the second world war Jack worked for the Emergency Medical Service in Newcastle, Liverpool, and Weymouth, treating soldiers wounded at Dunkirk and during D Day.

Jack returned to South Africa, working at the Brakepan Hospital and as a general practitioner in 1946-9, and then came back north to Guernsey in 1950 . He returned to Africa as a surgeon at the Haile Selassie Hospital, Ethiopia, in 1959, and finally returned to his native Ireland as resident surgical officer at Dr Steeven's Hospital, in Dublin, later that year. He also had a long career as an expert medical witness.

He leaves two grandchildren and two great grandchildren. [S C KoHLI, ANDrew GIBв]

Jack Stanley Gibson, surgeon and hypnotherapist Naas, County Kildare, Ireland (b 1909; q 1933; FRCSI, DTME'H), d 2 April 2005.

\section{James Stanley Cant}

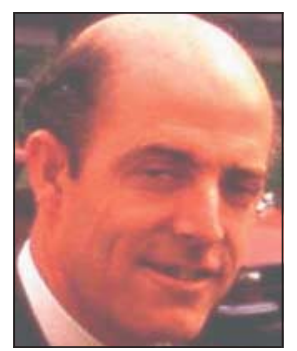

Former ophthalmic surgeon Glasgow (b Denniston, Glasgow, 1930; q Glasgow 1953; FRCS Glas, FRCS Ed, FRCOphth), d 28 March 2005.

Stanley Cant was consultant at the Victoria Infirmary and Southern General Hospital, Glasgow, and then at the Royal Hospital for Sick Children, Glasgow, and at the Tennent Institute of Ophthalmology at the Western Infirmary, where he held an honorary university senior lectureship. He was among the first to use transantral decompression in the management of endocrine exophthalmos. Disorders of ocular motility were a major interest and for many years he served on the British Orthoptic Board. Stanley had an irrepressible and impish sense of humour. Some 16 years before his death he was diagnosed as having terminal, inoperable pancreatic cancer. Much to everyone's surprise, he made a full recovery. He died from a heart attack at the breakfast table on his wedding anniversary. He leaves a wife, Margaret; three children; and seven grandchildren. [Wallace S Foulds]

\section{John Cedric Jones}

Former general practitioner Newport, Isle of Wight (b Wellingborough 1915; q St Thomas' Hospital, London, 1940), died 10 May 2005.

Cedric Jones served in the Royal Navy during the second world war on destroyers and fleet minesweepers from the Atlantic to the Far East, including a period on the Arctic convoys. In 1946 he went into practice with his father in Newport, Isle of Wight and they worked together until his father retired in 1951. Cedric retired from general practice in 1980 but did medical assignments until he was 72, including a short spell as a hospice doctor. Predeceased by his wife, Molly, he leaves three children and three grandchildren. [ADRIAN JoNEs]

\section{Norman Travers Pollitt}

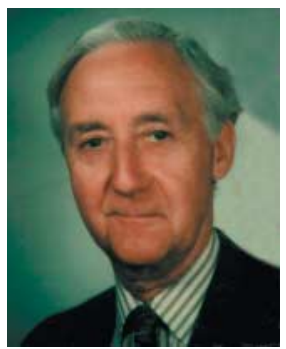

Former medical adviser Roche Products (b 1918; q St Mary's Hospital, Paddington, 1952; MRCGP), died on 5 April 2005 from a variant of motor neurone disease, which baffled the experts.

During the second world war he served in the Friends' Ambulance Unit, working in hospitals in London during the Blitz, and for three years in Ethiopia. After the war he assisted with refugees in Germany. Following hospital jobs he went into general practice in Newmarket, but could not keep his family on $£ 1200$ a year. He was a talented writer and his work was published in many periodicals. For the last few years he wrote using a voice-activated computer and corresponded with similarly disabled people worldwide. He leaves a wife, Rosemary, and three children. [A Holmes Pickering]

\section{Arthur Philip Booth Waind}

Former consultant general physician Barrow-inFurness, Cumbria (b 1915; q Leeds 1938; MD, FRCP), d 4 January 2005.

After qualifying Philip enrolled in the navy as a surgeon lieutenant at the outbreak of the second world war. In 1940 he was awarded the Distinguished Service Cross for outstanding courage and devotion to duty. He was mentioned in dispatches for two separate incidents, in one of which he was captured, spending years as a prisoner of war. Few of his longstanding colleagues knew of his wartime exploits and their deserved recognition. In 1950 he was appointed consultant physician in Barrow, retiring in 1979. He believed passionately in the NHS and was one of its early pioneers in Furness. He leaves a wife, Catherine, five children, and 14 grandchildren. [MALCOLM PALMer]

Longer versions of these obituaries are available on bmj.com 